\title{
RESEARCH ON OPERATION OF TASK PROCESS OF HYDRAULIC EXCAVATOR WITH MICROCOMPUTER
}

\author{
Feng Pei-en. Sun Shou-qian, Yang Yi. State Key Laboratory \\ of CADACG at Zhe.jiang University. Department of \\ Mechanical Engineering Zhe.jiang University \\ Hangzhou Zhe.jiang Postcode 310027 \\ P.R.China
}

\section{SUMARRY}

A test-board of microcomputer-operated hydraulic excavator with bucket is developed. Its power is $7.5 \mathrm{kw}$ and working pressure is $14 \mathrm{MPa}$. The technique of electrohydraulic proportional servo and two-level computer control is applyed. The operation of task process of excavator with microcomputer is to make pose of bucket approach trajectory obtained with the aid of planning. The methods of path and trajectory planning in view of high effect are further presented. The relevant control software is developed and the control of desired task process is realized on the test-board.

Keywords: excavator, task process, microcomputer-operated

\section{INTRODUCTION}

There are four ways to classify microcomputer-operated hydraulic excavators , depending on the level of planning system:

Master-slave telecontrol. The function of control-action-sensation is contained,e.g. PC200R-2 of KOMATSU Company [1983 ${ }^{[4}$.

Playback. The function of trajectory planning-control-execution-internal sensation is contained, e.s. test-board of shovel attachment of Tong.ji University $[1988][5]$

off-line programming. The function of task planning-path planning-tra.jectory planningcontrol-execution-internal sensation is contained. There is any external sensation. The in wired data of task coordinate system are obtained from the model database of an excavator and its environment,e.g.MS1600 of MITSUBISHI Company $\left[\left.1984\right|^{\text {i6? }}\right.$.

Part autonomous in view of force supervisory control. The function of task planning path planning-trajectory planning-external sensation is contained. The relation between of $\mathrm{f}-$ line excavated model and practiced excavated state is built with the aid of force supervisory control and condition programming. When excavator is overloaded, the correction for path in view of some common excavated state is realized,e.g. the microcomputer-operated hydraulic excavator developed by Soviet Union[1988].

A test-board of microcomputer-operated hydraulic excavator with task planning system has been operated recently in Institute of Machine Design Zhe.jiang University .

2. STRICTURE AND CONTROL PRINCIPLE OF TEST-BOARD OF MICROCOMPUTER-OPERATED HYDRAULIC EXCAVATOR WITH BUCKET

The test-board is shown in Fig. 1 . Its general data are: $7.5 \mathrm{KW}$ power, $0.02 \mathrm{~m}^{3}$ bucket capacity, $14 \mathrm{MPa}$ working pressure $25 \mathrm{l} / \mathrm{min}$ rate of flow, $1.8 \mathrm{~m}$ dumping height. $3 \mathrm{~m}$ maximium excavated radius and $1.5 \mathrm{~m}$ maximium excavated depth. 


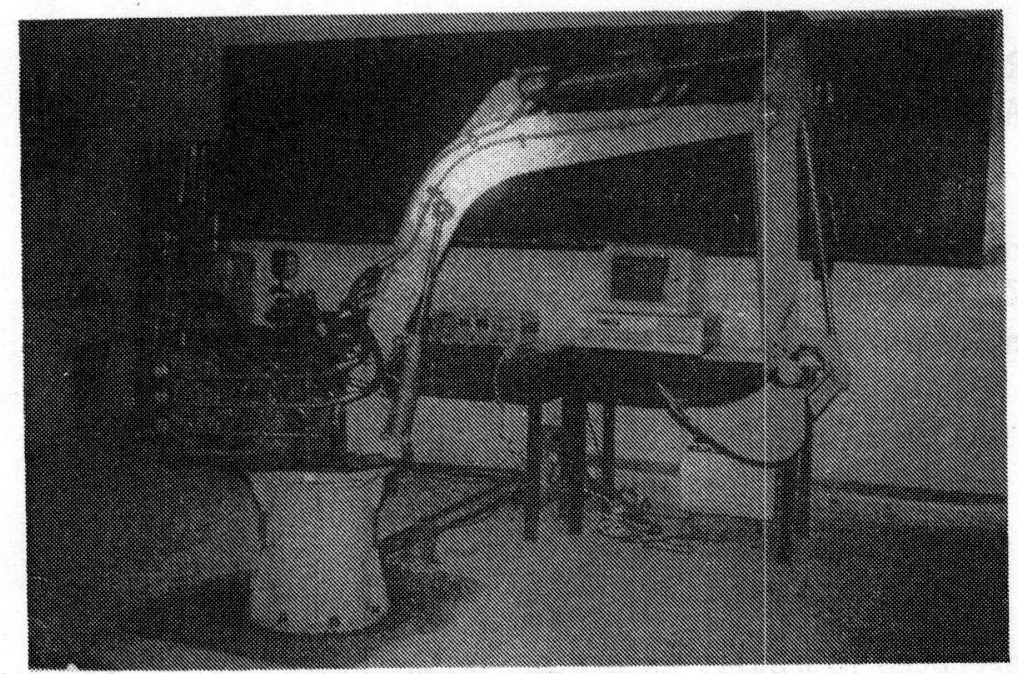

Fig. 1 The Test-board of Microcomputer Operated Hydraulic Excavator

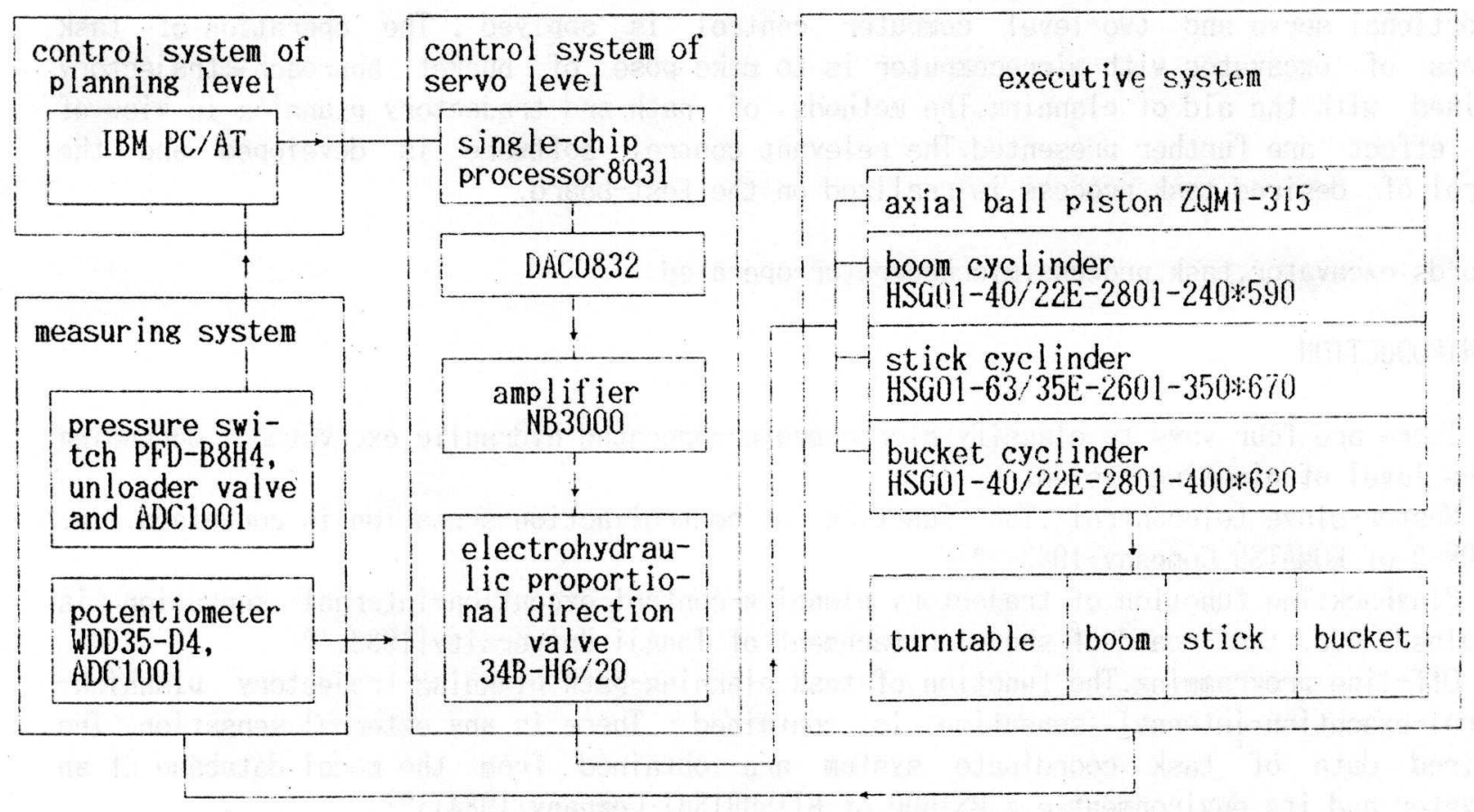

Fig.2 The Structure of Microcomputer Operated Hydraulic Excavator

parts,plánning control system,servo control system, executive system and measuring, system as shown in Fig.2.

Electrohydraulic proportional direction valve is adopted because in contrast to electrohydraulic servo valve it posseses the following merits:lower demand for cleanliness of hydraulic medium;larger absorbed power of electromechanical transducer and better reliability; lower working pressure difference and energe drain ; wider mid-position deadband and lower manufacturing cost.

Two-level computer control is adopted because in contrast to single computer control it possesses the following merits:definite division of labour with a computer used to planning control and the other to servo control;faired good man-machine interactive ability and programming ability.

\subsection{CONTROL PRINCIPLE}

What is called operation of task process of hydraulic excavator with microcomputer is to moko linomotis of hucket anoroach tra iectorv obtained with the aid of 
planning, i.e. task planning,path planning and trajectory planning. Space pose of bucket is determined by four joint angles. The operation of task process is realized with the aid of microcomputer controlling four angles.

The technique of two-level computer control is applyed here. The planning control is carried out with a PC/AT computer. When excavator is overload, the correction for path is realized with the aid of pressure switch. The servo control is carred out with a 8031 single-chip processor. The joint angles measured with the aid of potentiometer installed on joints of turntable, boom,stick and bucket. The single-chip processor calculates revolving angles of potentiometer after feedback voltage is carred into analog-to-digital converter and made sampling. The error of the revolving angles measured with respect to the revolving angles obtained with the aid of planning and its control amount based on the PID control algorithm is calculated. The digital singnal is carried into digital-to-analog converter, changed into the relevant analog amount and enlarged with the aid of power amplifier. The four circuits of electrohydraulic proportional servo driving system are drived to make joint angles measured approach joint angles obtained with the aid of planning. Thus operation of task process of hydraulic excavator with microcomputer is realized.

\section{CONTROL ALGORITHM OF PLANNING LEVEL}

At present there are a lot of task planning systems over the world ${ }^{[3]}$, which are limited in the situation of relavant fixed environment structure such as carrying and assembly. The hydraulic excavator with microcomputer has the following characteristics in contrast to industry robot:

- complicated, varied and irregular shape and properties of task object

- adverse circumstances,e.g. serious contamination

- peculiar hydraulic system and circuit

- low precision and large load

Many methods of task planning system of general industry robot can't be directly applyed to a hydraulic excavator with microcomputer.

Only at first the task planning system is built, can hydraulic excavator be operated with microcomputer ${ }^{[1][2]}$. The basic task of planning system is that path and trajectory is automatically practiced from initial state to final state in given work range. According to the type of problem the planning system is devided into three levels as follows:

- task planning:to solve sequence finishing the task.

- path planning:for every task sequence to solve a safe and high effect path that doesn't meet with other things such as task object,obstacles and self-dumping lorry.

- trajectory planning: to solve dynamic properties of velocity and acceleration when excavator moves along given path.

Take a typical cycle process of scooping as an example. The method and algorithm of planning control is discussed.

\subsection{PATH PLANNING OF A TYPICAL CYCLE PROCESS OF MICROCOMPUTER OPERATED HYDRAULIC EXCAVATOR}

Though there are various kinds of combination of basic task movement the single-handed action,e.g. of boom,stick and bucket and the compound-handed action.e.g. of turntable-boom and stick-bucket are firstly adopted to meet task demand.

In view of above-mentioned consideration path planning is done in accordance with a typical cycle process as follows: [7]

- excavate and load with filled bucket

The path is excavated with bucket cylinder.

- raise with filled bucket and swing

The boom is raised by boom cylinder, meanwhile bucket is raised with filled bucket end of excavating. After position of bucket is over ground, motor simultaneously swings to 
- dump

When bucket to dumping position, turntable is braked, and dumping radius is adiusted with stick cylinder. Then bucket cylinder is retreated and bucket is dumped.

- return with empty bucket

Turntable reversely revolves and empty bucket is put a new excavated position.

The Solution to path planning can be shown in Table 1.

Tabie 1. The Solution to Path Planning

\begin{tabular}{|c|c|c|c|c|c|c|c|c|c|c|c|}
\hline $\begin{array}{l}\text { sequence of } \\
\text { path }\end{array}$ & 1 & 2 & 3 & 4 & 5 & 6 & 7 & & & & 10 \\
\hline $\begin{array}{l}\text { turntable } \\
\text { boom } \\
\text { stick } \\
\text { bucket }\end{array}$ & 1 & 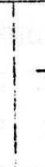 & 1 & 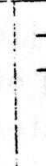 & - & 1 & 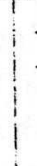 & & & & \\
\hline
\end{tabular}

\subsection{KINEMATIC PROBLEM}

The mixed kinematic problem also arised besides obverse kinematic problem and inverse kinematic problem here, as shown in Table 2.

Table 2 Classify of Kinematic Problem of Microcomputer-operated Hydraulic Excavator

\begin{tabular}{|c|c|c|c|}
\hline sequence & classify & known parameter & requested parameter \\
\hline 1 & obverse problem & $q_{1}, q_{2}, q_{3}, q_{4}$ & $p x, p y, p z, \zeta$ \\
\hline 2 & inverse problem & px,py, $z, \zeta$ & $q_{1}, q_{2}, q_{3}, q_{4}$ \\
\hline 3 & mixed problem & $p x, p y, p z, q_{4}$ & $q_{1}, q_{2}, q_{3}, \zeta$ \\
\hline 4 & mixed problem & $q_{1}, q_{2}, q_{3}, \zeta$ & $p x, p y, p z, q_{4}$ \\
\hline 5 & mixed problem & $p z, q_{1}, q_{3}, q_{4}$ & $p x, p y, q_{2}, \zeta$ \\
\hline 6 & mixed problem & $p z, \zeta, q_{1}, q_{3}$ & $p x, p y, q_{2}, q_{4}$ \\
\hline 7 & mixed problem & $p z, \zeta, q_{1}, q_{4}$ & $p x, p y, q_{2}, q_{3}$ \\
\hline
\end{tabular}

The mathematical model of solution to obverse kinematic problem of microcomputer operated hydraulic excavator is proposed with the aid of $\mathrm{D}-\mathrm{H}$ coordination frames and matrix transformation. Pose matrix is described by coordinate of bucket tip and horizontal inclination of bucket. Hence inverse and mixed kinematic problem are proposed.

Here the bucket position is described with coordinate,px,py and $p z$ and the oritation $\zeta$ of bucket with inclination of $0_{3} \mathrm{O}_{4}$ with respect to horizontal plane. The position and the oritation of bucket are called as bucket pose.Joint variables are chosen according to $\mathrm{D}-\mathrm{H}$ coordinate frames and are qualitatively described as horizontal revolving angle $q_{1}$ of turntable, horizontal inclination $q_{2}$ of boom, angle $q_{3}$ between boom and stick and angle $q_{4}$ between stick and bucket.

As shown in Fig. 3. a coordinate frame is assigned to each excavator link using the Denavit-Hartenberg convention ${ }^{[1]}$ to describe the position and orientation of link. The transformation from the coordinate frame of link $i-1$ to that of link is expressed by a series of simple translation and rotation transformation as follows:

1) rotate about the $z$-axis an angle $q_{i}$,

2) rotate about about the new $x$-axis an angle $a_{i}$,

3) translate along the new $x$-axis at distance $a_{i}$ and 
4) translate along the new z-axis a distance $d_{i}$.

$q_{1}, a_{i}, a_{1}$ and $d_{1}$ of the test-board are shown in Table 3.
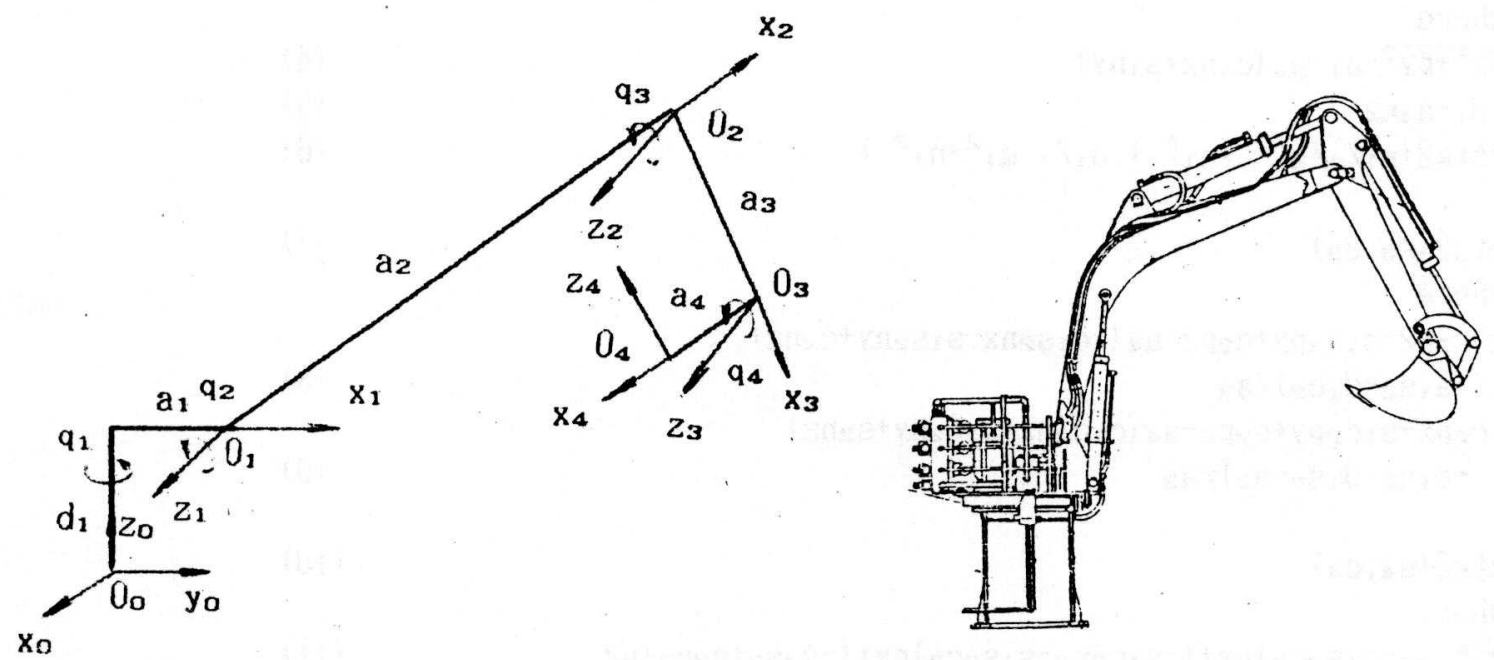

Fig. 3 The Coordinate Frame of the Test-board

Table $3 \quad a_{i}, a_{i}, a_{i}$ and $d_{i}$ of the Test-board

\begin{tabular}{|c|c|c|c|c|c|}
\hline joint $\mathrm{i}$ & $\mathrm{q}_{\mathrm{i}}$ & $\mathrm{a}_{\mathrm{i}}$ & $\mathrm{a}_{\mathrm{i}}$ & $\mathrm{d}_{\mathbf{i}}$ & range of $\mathrm{q}_{\mathrm{i}}$ \\
\hline 1 & $\mathrm{q}_{1}$ & $90^{\circ}$ & $1500 \mathrm{~mm}$ & $800 \mathrm{~mm}$ & $-180^{\circ} \sim+180^{\circ}$ \\
\hline 2 & $\mathrm{q}_{2}$ & $0^{\circ}$ & $1600 \mathrm{~mm}$ & 0 & $-23^{\circ} \sim+49^{\circ}$ \\
\hline 3 & $\mathrm{q}_{3}$ & $0^{\circ}$ & $850 \mathrm{~mm}$ & 0 & $-137^{\circ} \sim-43^{\circ}$ \\
\hline 4 & $\mathrm{q}_{4}$ & $90^{\circ}$ & $400 \mathrm{~mm}$ & 0 & $-132^{\circ} \sim+15^{\circ}$ \\
\hline
\end{tabular}

The solution to observe kinematic problem, the pose of bucket with respect to bare coordinate frame,

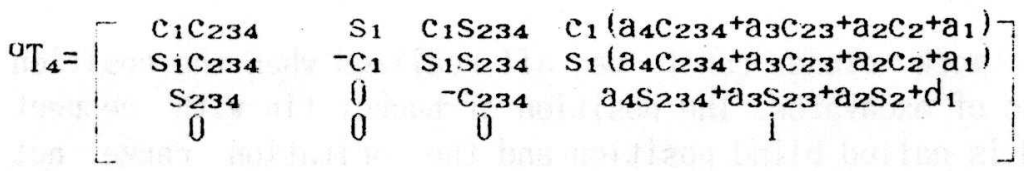

$$
\begin{aligned}
& =\left[\begin{array}{llll}
n & \text { s } & a & 0 \\
0 & 0 & 0 & 1
\end{array}\right]
\end{aligned}
$$

\footnotetext{
where

$\mathrm{s}-\sin$

c- $-\cos$

$\mathrm{i}-\mathrm{q}_{2}(\mathrm{i}=1,2)$

$23-a_{2}+q_{3}$

$234-q_{2}+q_{3}+q_{4}$
}

$A_{1}-0-H$ transformation matrix between $\mathrm{i}$ and $\mathrm{i}-1$

$\mathrm{n}$-vector along $\mathrm{O}_{3} \mathrm{O}_{4}$ or $\mathrm{x}_{4}$

$\mathrm{s}$ vector along $\mathrm{y}_{4}$

a vector along $\mathrm{Z}_{\mathbf{4}}$ 
The solution to inverse kinematic problem:

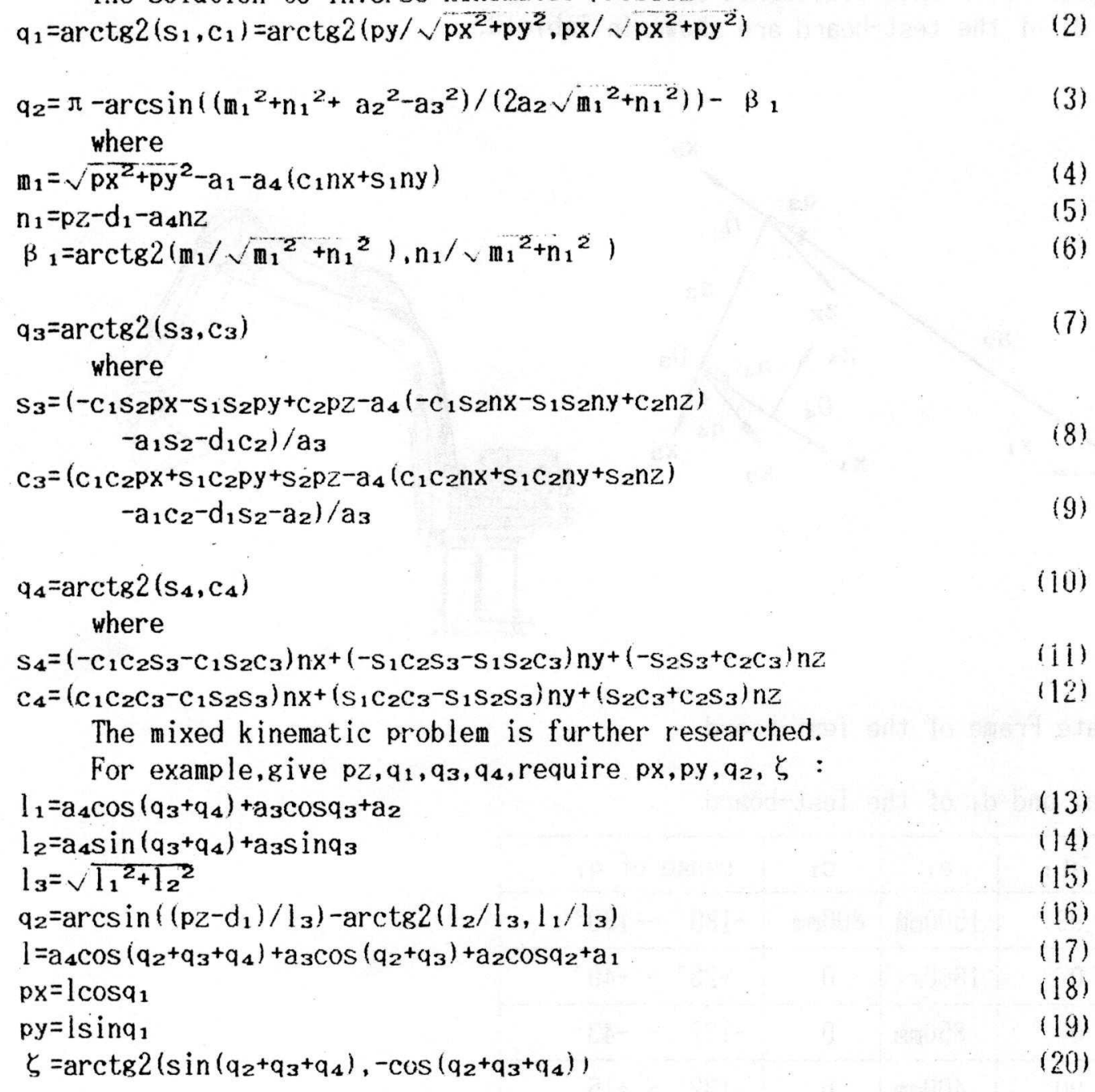

\subsection{CONCEPT AND CRITERION OF BLIND POSITION AND BLIND ANGLE 272}

Kinematic limit of excavator means as follows:

- position limit of bucket tip, work range of excavator

- oritation limit of bucket

Oritations of range $360^{\circ}$ in work plane can't be all realized when the position of bucket tip is given in work range of excavator. The position of bucket tip with respect to the oritation range not realized is called blind position and the oritation range not realized itself is called blind angle. As there are blind position ard blind joint, the given oritation can't be realized when path point of bucket is given. It meams that excavator can't meet meanwhile the demand for arbitrary position and oritation of bucket . Feasiblity of pose of every path point must be judged in advance.

The blind position can be judged according to whether revolving angle of every joint goes beyond the range of revolving joint.

\subsection{TRAJECTORY PLANNING IN VIEW OF ACTUATOR VARIÄBLE SPACE}

Here translation between joint variable space and actuator variable space is introduced.

The translation of joint variable space with respect to actuator variable space is applyed to solution to amount of actuator variable of every path point. The translation of actuator variable space with respect to joint variable space is applyed to algorithm of 
For meeting demand for work process, rate of flow must be reasonally distributed to raise work velocity and shorten work time. In addition,for meeting demand for smoothness of task process, velocity of every path position must be smoothly transitioned nearby, so trajectory algorithm of multi-stage of uniform motion with parabola as transition region in view of actuator variable space is proposed.

Considered condition of boundary:

- give $x_{1}, \ldots, x_{n}$;

- give $\left|\cdot d^{2} x_{1} / d t^{2}\right|, \ldots, d^{2} x_{n} / d t^{2} \mid$

(Enough larger acceleration must be given to have enough longer linear region; $\mathrm{d}^{2} x_{1} / d \mathrm{~d}^{2}=\operatorname{SGN}\left(x_{2}-x_{1}\right) \mid \mathrm{d}^{2} x_{1} / \mathrm{dt}^{2}$

$d^{2} x_{n} / d t^{2}=\operatorname{SGN}\left(x_{n-1}-x_{n}\right)\left|d^{2} x_{n} / d^{2}\right|$

$d^{2} \times, j / d t^{2}=\operatorname{SGN}\left((d x / d t)_{s k}-(d x / d t)_{i s}\right)\left|d^{2} x_{j} / d t^{2}\right|(j=2 \ldots \ldots n-1)$

- give $d x_{1} / d t, d x_{n} / d t$

- continuous velocity.

The algorithm of trajectory planning between $i$ and $j$ :

$x=a_{11, j} t^{2}+b_{11, j} t+c_{1 i j}\left(t \in\left[0, t_{0 i j}\right]\right)$

$x=a_{21, j} t+b_{21, j} \quad\left(t \in\left[t_{01, j}, t_{d i, j}-t_{r i, j}\right]\right)$

$x=a_{3 i, j} t^{2}+b_{3 i, j} t+c_{3 i s}\left(t \in\left[t_{d i, j}-t_{f i j}, t_{d i, j}\right]\right)$

where

to $\mathbf{j}$ continued time of acceleration phase between $i$ and $j$

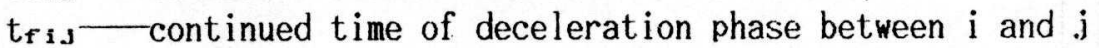

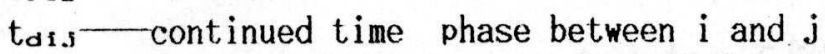

$a_{113}, b_{1 i j}, c_{11 j}, t_{01 j}, a_{21 j}, b_{21 j}, t_{f 13}, a_{313}, b_{31, j}, c_{3 i j}$ are solved according to condition of boundary.

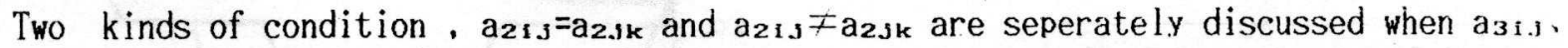
$b_{3 i j}, c_{3 i j}$ and $t_{f i j}$ are solved.

4. CONTROL ÁLGORITHM OF SERVO LEVEL

Because of a lot of working conditions and varied loads, the servo driving system is faced with several problems of strong interference, varied inertia and conpling, great difference of hydraulic parameter and varied transmission ratio. The PID control algorithm of varied gain is adopted.

$p(n)=K_{p}\left(e_{n}+T_{s} / T_{1} \Sigma e_{i}+T_{d} / T_{s}\left(e_{n}-e_{n-1}\right)\right)$

where

- if $K_{p}$ is increased, the response of system quickens. But over large $K_{p}$ can make system have too large overshoot, oscillate and its stability worse.

- if $T_{i}$ is increased, overload is reduced to make system stable, but the elimination of static deflection is slowed down.

- if $T_{d}$ is increased, the response of system quickens to reduce overshoot, increase stability and reduce restrained ability to interfere signal.

$K_{p}, T_{s}, T_{i}$ and $T_{d}$ are defined through repeated experiments.

\section{EXAMPLE}

5.1 CONTROL MECHANISM OF A TYPICAL CYCLE PROCESS OF SCOOPING

The control mechanism of a typical cycle process of scooping is shown in Fig. 4. 
The display of result of three-dimensional dynamic simulation and dynamic characteristic is seperately shown in Fig. 5 and Fig.6.

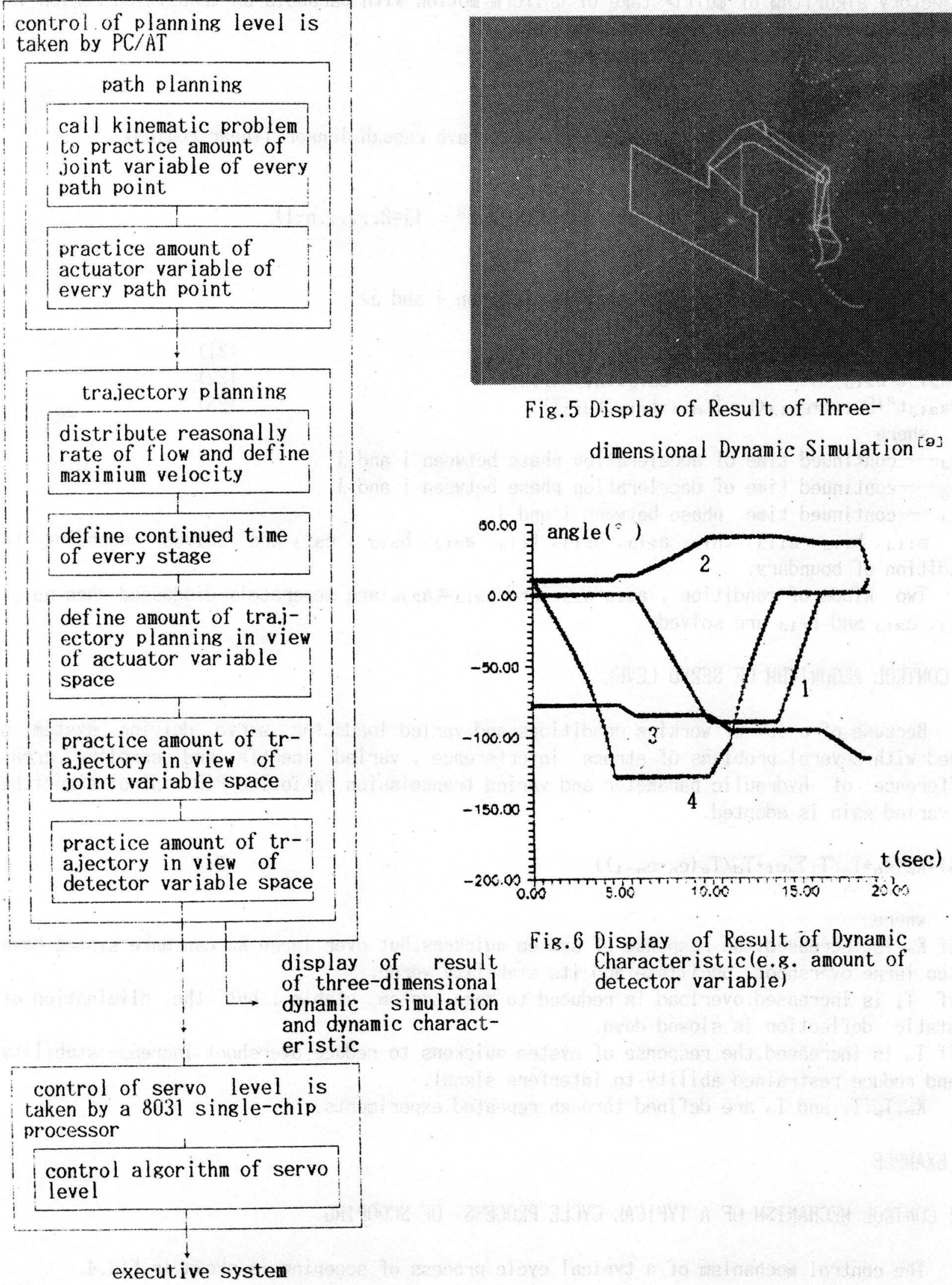

Fig.4 The Control Mechanism of a Typical Cycle 


\section{CONCLUSION}

At present the control of typical task cycle process has been realized on the testboard of microcomputer-operated hydraulic excavator. The research on that when excavator is overloaded correction for path is realized with the aid of pressure switch will be introduced in other paper.

\section{REFERENCES}

(1) Paul,R.P,Bobot Manipulators:Mathmatics,Programming and Control, MIT Press, 1981.

2]蔡自兴: 机器人原理及其应用, 中南工业大学出版社, 1988 年8月。 (Cai Zi-xing, "Robotics:Principles and Applications". Middle South Industrial University Publishing House. 1988.8.)

(3) Fikes, R.E., and Nilsson.N.J."STRIPS:A New Approach to the Application of Theorem Proving to Problem Solving ".Artificial Intell igence, vol.2, no. 3/4.

4] 近石康司 (Japanese), "PC200R-2 Radio-Controlled Hydraulic Excavator", Komatsu Technical Review, 1983.3.

5 曹善华、俆志新：液压挖掘机工作装置的运动轨迹的微机控制，侪大学学报，1988.1。 (Cao Shan-hua, Xu Zhi-xin(Chinese)," Research on. Trajectory Control of the Shovel st Lachment of Hydraulic Excavator with Microcomputer", Journal of Tong.ji University, 1988.1.vol.16.)

6) 中野达郎 (Japanese), "Development of Large Hydraulic Excavator MS1600", MITSUBISHI JUKO GIH0, vol.22. No 1.1 1985.

7 孙守迁: 要培思, 全办所: 微机操纵液压挖掘机反铲典型作业循环过程路经规划及其运动学的研究, 工程机械)，1991年(已录用): (Sun Shou-qian, Feng Pei-en, Quan Yong-xin (Chinese)。 "Investigation on Path Planning of Typical Task Cycle Process and Kinematics of Microcomputer-operated Hydraulic Excavator Backhoe", Journal of Engineering Mechanics, 1991. (emp loyed)!

8: 孙守诖, 冯培恩, 全承所: 微机操纵液压挖掘机反铲典型作业循环过程的轨迹规划, 北京首届国阿 机电一体化学术讨论会论交, 1991 年1 0 月。 (Sun Shou-qian, Feng Pei-en, Quan Yong-xin, "Investigation on Tra jectory Planning of Typical Task Cycle Process of Microcomputer-operated Hydraulic Excavator with Bucket", The First Beijing International Symposium on Mechatronics, 1991.10.)

9]齐中伟, 冯培恩: 液压挖掘机作业过程的三维图形动态仿真软件 , 浙江大学机械设计研究所, 1990.8 QQi Thong-wei,Feng Pei-en(Chinese),"A Three-domensional Dynamic Simulation Sof tware of Task Process of Hydraulic Excavator", Institute of Machine Design Zhe.jiang University , 1990.8.) 
Nikolay G. Yemelianenko - Dozent, Department of Mechanization of Construction Processes. Kharkov Civil Engineering Institute Sumskaya Str., 40 office (0572) 40-29-65

Valentin A. Tokarev - postgraduate Kharkov Civil Engineering Institute Sumskaya Str., 40 ofice (0572) 40-29-65

Designing and Investigation of Pneumohydraulic Drive of Vibratory Compactor

Vibratory compactors with directed vibration are used in fabrication of precast reinforced concrete. The most widely used compactors are those with operation modes with frequency or 25-50 Hz and range of $0 ; 5-0,7 \mathrm{~mm}$.

Lately in the USSR new low-vibration compactors were designed, which with symmetrical mode compact movable composition, while with asymmetrical mode they compact stiff compositions.

We've designed a new construction of pneumohydraulic drive of vibratory compactor for generating a low-frequency vibrations. The form filled with concrete is installed on the stocks of hydraulic rollers: the pistons of those rollers are vibrated by elastic cameras with pneumopulsators through the liquid.

The experimental investigations showed low frequency of $2-15 \mathrm{~Hz}$ and range of 2-15 mm. We've also employed alternative (controlable) operating modes: from vibration with low frequency and high range to the vibration with high frequency and small range.

The application of drive with controlable modes (low frequency and bigrange) allows to prolong the service life, decrease the noise, improve the quality of production. Pneumohydraulic drive can be also used in other types of vibratory machines: vibratory conveyers, impact screens $\in t c$. 
Ivan I. IVazarenko - the Chief of Department of Operation and Waintenance of Construction Machines, Professor, Doctor of Science (Technology). 252037, Kiev

Vozduchoflotsky Av,, 31

Kiev Civil Engineering Institute.

Howe (044) $-290-31-72$

orfice (044)-272-95-48

Inga A. Yemelianova- Docent, Canäidate of Science (Technology). 310002 , Kharkov

Sumskaya Str., 40,

Kharkov Civil Engineering Institute.

Department of Mechanization of Construction Processes.

Home (0572) 47-05-84

office (0572) 40-29-65

Concreting with Rotor-Throwers

Different kinds of rotor-throwers for placing of stiff construction compositions with simultaneous spreading and vibrationless compaction were designet and protected by a block of author certificates in the USSR and patented in FRG.

Field of application - concrete and finishing works in hydroconstruction, tunnels and mountain mines; lining in cement furnaces, fabrication of fiberconcrete elements. The provision of a stepless and rapid variation of machine operating modes allows it to be used for moulding elements of different strengths (20..50 MPa) and widths. hathematical model of operating process of mechanical splashing was worked out. We've obtained the regression equations which determine the dependence of physical and mechanical properties of splashed concrete on operating parameters.

The phenomenon of "bouncing" was investigatedithroughly. The process of composition splashing with rotor-throwers can be completely mechanized and automated. There is a possibility of using cement-savine compositions (cement saving amounts to $5 \ldots 7 \%$ per $1 \mathrm{~m}^{5}$ ), producing homogenous and dense concrete (V8...V12) with high strength and heat-resistance; increasing the productivity 4-5 times, decreasing the amount of "bouncing" for $10-15 \%$ as compared with pneumatic concrete. We've obtained positive results of experimental and industrial production in finishing and tiler work as well as of fabrication of 
Referat für das 8. Internationale symposium "Automatisierung und Roboter im Bauwesen I.S.A.R.C."

Dipl.-Ing. Hans stiglocher, Bauunternehmer, Burghausen

Warum braucht die Bauwirtschaft mehr Automatisierung und Robotereinsatz im Bauwesen?

Meine Damen und Herren,

Sie wissen, daß es der Bauwirtschaft in der Bundesrepublik Deutschland, und ich meine hier die alten Bundesländer, zur zeit gut und teilweise sogar sehr gut geht. Sie wissen, es gibt optimisten und Pessimisten auch in der Bauwirtschaft. Die Pessimisten befürchten einen baldigen Einbruch der gegenwärtigen Baukonjunktur, die optimisten erhoffen das Gegenteil. Ich meine, es wäre unserer starken und bedeutenden Branche mit 60000 fast ausschließlich mittelständischen Unternehmen am ehesten gedient, wenn der eingeschlagene Wachstumspfad stetig weiter beschritten werden könnte, und wenn es weiterhin wachstumszahlen mit auch nur geringen steigerungsraten gibt, wenn also die Bauwirtschaft sich in ihrer jetzigen Größe und Bedeutung stabilisiert und konsolidiert. Mit einem satz: Wenn wir alle erkennen können, daß Bauen weiter zukunft hat und sich auf diese zukunft weiter bauen 1 äßt.

Ich kann hier nur betonen, daß insgesamt gesehen, die Bedeutung der Bauleistung für unsere Volkswirtschaft für unsere Entwicklung gar nicht hoch genug eingeschätzt werden kann. Ein weiterer Aspekt dabei ist der wert des gesamten reproduzierbaren Anlagevermögens in unserem Land. Dieser wird gegenwärtig zu Wiederbeschaffungspreisen runde 7,5 Billionen Mark beziffert. Etwa $80 \%$ des Vermögens bestehen aus Bauten. Die Bausubstanz hat einen Wert von rund 6 Billionen Mark! Allein um dieses gewaltige Bauvermögen $z u$ erhalten, benötigen wir fortlaufend umfangreiche Bauleistungen. Deren Ausmaß hängt von der angenommenen durchschnittlichen Lebensdauer der einzelnen Bauwerke ab. Das statistische Bundesamt geht von einem durchschnittlichen Abschreibungssatz von $2 \%$ aus. Es rechnet demnach mit einer Lebensdauer von unter 50 Jahren. Allein zum Erhalt des bestehenden Bauvolumens müssen gegenwärtig also jährlich mehr als 120 Milliarden Mark aufgewendet werden. Dieser Wert entspricht ziemlich genau 
der Hälfte des derzeitigen Bauvolumens. Alle Angaben beziehen sich auf das ehemalige Gebiet der Bundesrepublik Deutschland ohne die bisherige DDR.

Meine Damen und Herren, wesentlich ist, die zukunft unseres Gewerbezweiges ist und bleibt eng mit dem Schicksal unserer gesamten Volkswirtschaft verbunden. Darin wird auch der künftige gemeinsame Binnenmarkt der EG grundsätzlich nichts ändern. Der größte Markt mit seinen mehr als 120 Millionen Menschen wird im Gegenteil die Schlüsselrolle der Bauwirtschaft noch stärker hervorheben. Ich denke hierbei vor allem an die notwendigen europaweiten Verkehrsinvestitionen. Hier stehen wir vor gewaltigen zusätzlichen Aufgaben.

Trotzdem sind wir, was die Entwicklung Europa 1992 oder besser gesagt 1993 angeht, nicht ohne Sorge. Zumindest in grenznahen Gebieten ist damit $z u$ rechnen, daß ausländische Bauunternehmen verstärkt ihre Leistungen anbieten werden. Das hohe deutsche Personalkostenniveau-verschafft Unternehmen aus billigeren Mitgliedsstaaten dabei ohne Zweifel wettbewerbsvorteile. Umgekehrt wird es deutschen Unternehmen sehr schwer sein, bei Bauobjekten in anderen Mitgliedsstaaten zum zuge zu kommen. Unter diesen Umständen gewinnt der Qualitätsgedanke noch mehr an Bedeutung. Nur mit qualitätsmäßig hochwertigen Leistungen können unsere überwiegend mittelständischen Betriebe bestehen. Das Qualitätsniveau kann nur gehalten oder verbessert werden unter Einsatz moderner Maschinen. Die zukunft verlangt Bauleistungen mit know-how, die nur mit Maschinen mit high tech $z u$ erbringen sind. Heute zeichnet sich ab, daß auch bei mobilen Maschinen die Entwicklung neuer Methoden in der Konstruktionstechnik, durch Anwendung neuer und verbesserter Werkstoffe, leistungsfähigere steuerung, Regelung und Automatisierung unter Einsatz von Mikroprozessorsteuerung auch bei schweren Arbeitsmaschinen wachsende Bedeutung erlangen wird.

Ein besonders wichtiger Bereich sind für uns aber die kleinen und mittleren Maschinen, die für den flexiblen Dauereinsatz bei

Neubauvorhaben wie auch bei Arbeiten in der vorhandenen Bausubstanz eingesetzt werden können. Das sind Maschinen, die klein und mobil sind und mit unterschiedlichen Anbauteilen von wechselndem Personal bedient 
werden können. Diese Maschinen müssen wartungs- und verschleißarm sein, sich selbst kontrollieren und den Beanspruchungen der Baustelle mit staub, Feuchtigkeit und Temperaturschwankungen standhalten. Dem Qualitätsgedanken entsprechend müssen geringste Toleranzen in der Bauproduktion eingehalten werden. Diese Forderungen lassen sich nur durch mehr Elektronik in der Maschinenüberwachung und in der Maschinensteuerung erzielen, ebenso wie möglichst weitgehende Automatisierung die menschlichen Unzulänglichkeiten ausschalten muß. Ich brauche also das kleine Helferlein für alle Fälle, das über Funkfernsteuerung Arbeitsbewegungen mit höchster Effektivität ausführt.

Meine Damen und Herren,

dies ist notwendig, um unsere Wettbewerbsfähigkeit im EG-Binnenmarkt $\mathrm{zu}$ steigern. Die Bauwirtschaft in der Bundesrepublik Deutschland ist mit besonders hohen Lohn- und Lohnzusatzkosten belastet. Gleichzeitig stellt sich die Frage, ob unser wirtschaftszweig - der Bau - auch in zukunft genügend qualifizierte Mitarbeiter hat. Die Bauwerke werden von Fachleuten errichtet und ausgeführt. Bauen ist und bleibt eine handwerkliche Tätigkeit - mit immer mehr Unterstützung von modernen Geräten und Maschinen. Dafür brauchen wir den handwerklich qualifizierten Facharbeiter, den Facharbeiter, den uns heute schon und mehr noch morgen fehlt.

Aus den über die Sozialkassen der Bauwirtschaft erfaßten Lebensdaten der Mitarbeiter wird ganz klar ersichlich, daß jetzt schon mehr als $40 \%$ aller im Bauhauptgewerbe beschäftigten Arbeitnehmer das 45. Lebesjahr überschritten haben. Bei den polieren und schachtmeistern sieht es noch schlimmer aus. Das bedeutet, daß die Bauwirtschaft allein wegen dieser Altersstruktur in den gut 11 Jahren bis zur Jahrtausendwende etwa $40 \%$ ihrer Arbeitnehmer einbüßen wird. Ein Ausgleich dieses enormen rein altersbedingten Abbaus von Arbeitskräften wird dann nicht möglich sein, wenn die Zahlen der Lehrlinge um mehr als $30 \%$ zurückgehen, wie dies regional unterschiedlich seit dem Herbst 1985 registriert wird.

Bei der bedrohlichen Lehrlingssituation ist der schlag des pendels vielleicht schon an seinem Tiefpunkt angelangt, jedenfalls sind 
die Rückgänge der zahlen für die

Auszubildenden im 1 . Lehrjahr zuletzt merklich geringer geworden.

Ursache für den Nachwuchsmangel insgesamt ist jedoch nicht nur der Rückgang der Geburtenzahlen, der sogenannte "Pillenknick", sondern speziell für die Bauwirtschaft das schlechte Image unseres Gewerbes. Bauen wird verbunden mit schwerer körperlicher Arbeit, arbeiten unter freiem Himmel, bei Kälte und Schnee, großer staubentwicklung und viel Lärm. Die Arbeitsplätze in anderen Branchen, die mit EDV-Unterstützung arbeiten, wie z.B. in Banken und Versicherungen werden von Schulabgängern auch mit hohem Bildungsniveau bevorzugt. Damit habe ich insgesamt die wesentlichen Kriterien unserer Probleme für die zukunft aufgezeigt. Wir haben $z u$ wenig qualifiziertes Fachpersonal, wobei die Probleme für die Zukunft weiter zunehmen durch die überalterung des vorhandenen Personals und weniger Nachwuchs. Ein Ausgleich hierfür können nur intelligente Baumaschinen sein.

Um die wenigen vorhanden, gut qualifizierten Baufachleute am Bau zu halten, ist man in der Bundesrepublik Deutschland gezwungen, sehr hohe Löhne zu zahlen. Die hohen Löhne beeinträchtigen die Wettbewerbsfähigkeit im europäischen Raum. Eine Leistungssteigerung auch im Hinblick auf die Humanisierung des Arbeitsplatzes ist jedoch nur mit modernen intelligenten Baumaschinen möglich.

Das hohe Lohnniveau und der Wettbewerbsdruck zwingt die deutschen Bauunternehmer Hochpreisprodukte anzubieten. Diese Produkte müssen aber ein über das normale hinausgehende Qualitätsniveau mit dauernder Qualitätssicherung haben. Diees ist in der Regel nur mit modernen intelligenten Baumaschinen zu erreichen.

Meine Damen und Herren,

jeder von Ihnen weiß, daß auch die modernsten Maschinen sich nicht ohne hochqualifiziertes Fachpersonal auf der Baustelle einsetzen lassen. In den Berufsförderungswerken der deutschen Bauwirtschaft werden unsere Mitarbeiter nach dem neuesten stand der Baumaschinentechnik aus- und weitergebildet. Auf diesem Gebiet sind wir in der EG führend.

Lassen sie mich zum Schluß auf eine sehr positive Entwicklung hinweisen, die mir sehr am Herzen liegt. Die Humanisierung des 
Arbeitsplatzes. In der Bezeheung Mensch Maschine -Umwelt hatten es unsere Mitarbeiter früher oft nicht leicht. Sie wurden hohen köperlichen Beanspruchungen ausgesetzt. Hier wurden positive Entwicklungen im Hinblick auf Lärmschutz, Vibrationsdämpfung und

Verbesserung der Bedienungsqualität aufgezeigt. Ich denke hier nicht nur an die schweren Arbeitsmaschinen, sondern auch an die Kleingeräte mit high tech unter dem Gehäuse.

Meine Damen und Herren,

lassen sie mich abschließend meinem Thema ensprechend zusammenfassend folgende Feststellung treffen. Die Zukunftsperspektiven am Bau und für den Baumaschinenhersteller sind wieder gut. Sie sollten es auch für einen überschaubaren zeitraum bis zur Jahrtausendwende bleiben.

Der Thnen hier auf diesem syposium gegebene umfassende überblick über die aktuelle Technologie, über richtungsweisende Problemlösungen und Rationalisierungsvorschläge, Impulse und Konzepte für mehr Leistung, mehr Bedienungskomfort, mehr sicherheit und mehr Umweltschutz ist ein weiterer schritt in die richtige Richtung. Nur mit intelligenten Baumaschinen, mehr Automatisierung.und robotergesteuertem Einsatz auf der Baustelle lassen sich die künftigen komplizierten und anspruchsvollen Bauvorhaben bezahlbar verwirklichen.

Ich danke Ihnen. 